\title{
Small-molecule aggregation inhibitors reduce excess amyloid in a trisomy 16 mouse cortical cell line
}

\author{
ANDRÉA C PAULA-LIMA ${ }^{*}$, CHRISTIAN ARRIAGADA $^{2 *}$, RODRIGO TORO $^{4}$, \\ ANA MARÍA CÁRDENAS ${ }^{4}$, RAÚL CAVIEDES $^{3}$, SERGIO T FERREIRA ${ }^{1}$ \\ and PABLO CAVIEDES ${ }^{3}$
}

\footnotetext{
${ }^{1}$ Program of Cell Biophysics and Biochemistry, Instituto de Bioquímica Médica, Universidade Federal do Rio de Janeiro, Rio de Janeiro, RJ 21941-590, Brazil

2 Program of Anatomy \& Developmental Biology and ${ }^{3}$ Program of Molecular \& Clinical Pharmacology, ICBM, Faculty of Medicine, University of Chile, Clasif 7-Independencia, Independencia 1027, Santiago, Chile

${ }^{4}$ Centro de Neurociencia de Valparaíso, Facultad de Ciencias, Universidad de Valparaíso, Valparaíso, Chile

* These authors contributed equally to this work
}

\begin{abstract}
We have previously characterized a number of small molecule organic compounds that prevent the aggregation of the $\beta$-amyloid peptide and its neurotoxicity in hippocampal neuronal cultures. We have now evaluated the effects of such compounds on amyloid precursor protein (APP) accumulation in the $\mathrm{CTb}$ immortalized cell line derived from the cerebral cortex of a trisomy 16 mouse, an animal model of Down's syndrome. Compared to a non-trisomic cortical cell line (CNh), CTb cells overexpress APP and exhibit slightly elevated resting intracellular $\mathrm{Ca}^{2+}$ levels $\left(\left[\mathrm{Ca}^{2+}\right]_{\mathrm{i}}\right)$. Here, we show that the compounds $2,4-$ dinitrophenol, 3-nitrophenol and 4-anisidine decreased intracellular accumulation of APP in CTb cells. Those compounds were non-toxic to the cells, and slightly increased the basal $\left[\mathrm{Ca}^{2+}\right]_{\mathrm{i}}$. Results indicate that the compounds tested can be leads for the development of drugs to decrease intracellular vesicular accumulation of APP in trisomic cells.
\end{abstract}

Key terms: Alzheimer's disease, Down syndrome, intracellular amyloid, murine trisomy 16, small molecule inhibitors.

\section{INTRODUCTION}

Alzheimer's disease (AD) is a progressive neurodegenerative disorder and the most common form of dementia in the elderly population. The disease is neuropathologically characterized by the presence of neurofibrillary tangles and senile or amyloid plaques in vulnerable brain regions, such as the cerebral cortex and hippocampus. Despite considerable efforts aimed to understand the molecular and cellular basis of $\mathrm{AD}$, there are currently no effective treatments to cure it or to arrest its progression (De Felice and Ferreira, 2002).

It is widely accepted that the $\beta$-amyloid peptide $(A \beta)$, derived from proteolytic processing of the membrane-bound amyloid precursor protein (APP), plays a central role in the neuropathology of AD (Hardy and Selkoe, 2002). Amyloid plaques are thought to arise from gradual extracellular $\mathrm{A} \beta$ deposition in fibrillar aggregates that have been extensively implicated in

ABBREVIATIONS: A $\beta, \beta$-amyloid peptide; AD, Alzheimer's disease; $\mathrm{CNh}$, neuronal cell line derived from the cerebral cortex of a normal mouse; $\mathrm{CTb}$, neuronal cell line derived from the cerebral cortex of a trisomy 16 mouse; FBS, fetal bovine serum; PBS, phosphate buffered saline; 2,4-DNP, 2,4-dinitrophenol; 3-NP, 3nitrophenol; 4-AA, 4-anisidine; NGF, nerve growth factor; $\left[\mathrm{Ca}^{2+}\right]_{i}$, intracellular $\mathrm{Ca}^{2+}$ levels; PMSF, phenylmethylsulfonylfluoride. 
neurotoxicity (for early examples, see Lorenzo and Yankner, 1994, Pike et al., 1995). More recent studies have indicated, however, that early synaptic dysfunction in AD is caused by accumulation and synaptic targeting by soluble $A \beta$ oligomers (Lacor, 2007, Ferreira et al., 2007, Haass and Selkoe, 2007). Moreover, recent reports have also shown that early intracellular $\mathrm{A} \beta$ accumulation can be detected in the brains of affected individuals (Gouras et al., 2000) and in transgenic mice that develop $A \beta$ plaques (Wirths et al., 2001) and that accumulation occurs especially in intracellular vesicular bodies (Langui et al., 2004, Takahashi et al., 2002). Intracellular $\mathrm{A} \beta$ has been proposed to play an important role in neurotoxicity (Glabe, 2001, KienlenCampard et al., 2002) and to be involved in early AD pathogenesis (Gouras, 2005).

Down syndrome (DS), the major cause of mental retardation in the world, is characterized by an extra copy of chromosome 21 (trisomy 21). Indicating a relationship between the pathophysiologies of AD and DS, all DS individuals eventually develop AD neuropathology at an early age, with characteristic accumulation of cerebral amyloid plaques by the fourth decade of life (Geller and Potter, 1999). This is consistent with the fact that the APP gene is located on chromosome 21 and, therefore, is overexpressed in DS individuals (Galdzicki and Siarey, 2003). Furthermore, early intracellular accumulation of $A \beta$ has also been observed in DS (Gouras et al., 2000).

Due to the partial genetic homology between mouse chromosome 16 and human chromosome 21 , murine trisomy 16 is considered a model for both $\mathrm{DS}$ and $\mathrm{AD}$ (Galdzicki and Siarey, 2003). Specifically, the APP gene is present in murine autosome 16 (Galdzicki and Siarey, 2003). However, the murine trisomy 16 condition is not viable and animals die in utero. This drawback has limited the use of those animals to studies of early developmental stages and to the use of primary cell cultures (Galdzicki and Siarey, 2003). In this regard, an interesting development has been the establishment of an immortalized cell line $(\mathrm{CTb})$ derived from the cerebral cortex of a trisomy 16 mouse fetus (Allen et al., 2000, Cárdenas et al., 1999). This cellular model has been well accepted for the study of DS and AD pathologies (for a review, see Saud et al., 2006). Compared to an age-matched immortalized cortical cell line $(\mathrm{CNh})$ derived from the cerebral cortex of a normal animal, CTb cells present slightly increased basal intracellular calcium levels and glutamatergic and cholinergic dysfunction (Allen et al., 2000, Cárdenas et al., 1999). Interestingly, CTb cells exhibit abnormally elevated intracellular levels of APP, which accumulates in vesicular bodies that positively stain with Congo Red (Arriagada et al., 2007, Opazo et al, 2006). Further, using immunoblotting and immunohystochemical techniques, such deposits have been shown to react with various antibodies that recognize different sequences in the APP molecule (Arriagada et al., 2007). Additionally, Opazo et al. (2006) recently showed that knockdown of APP in CTb cells normalizes cholinergic function, and proposed that specific gene overdose in Ts 16 could explain membranerelated dysfunction associated with receptors and ion channels, particularly in cholinergic cells.

We have previously characterized a number of small molecule inhibitors of the oligomerization and fibrillization of $A \beta$, which potently protect hippocampal neurons against $A \beta$-induced neurotoxicity (De Felice et al., 2001, 2004). Considering their moderately hydrophobic nature, we hypothesized that some of those compounds would be able to cross cell membranes and could also be effective in decreasing amyloid accumulation in intracellular compartments. Here, we show that treatment with low, non-toxic concentrations of 2,4-dinitrophenol, 3nitrophenol and 4-anisidine decreases the intracellular accumulation of amyloid in vesicular bodies in the $\mathrm{CTb}$ cell line. These results suggest that these compounds could be used as leads for the development of inhibitors that target both extracellular and intracellular amyloid accumulation. 


\section{METHODS}

The $\mathrm{CNh}$ and $\mathrm{CTb}$ immortalized cell lines were established and characterized as previously reported (Allen et al., 2000, Cárdenas et al, 1999). For standard growth conditions, cell lines were maintained in DMEM/F12 medium (Sigma, St. Louis, MO) containing $6 \mathrm{~g} / \mathrm{L}$ glucose, $1 \mathrm{~g} / \mathrm{L}$ sodium bicarbonate, $10 \%(\mathrm{v} / \mathrm{v})$ fetal bovine serum (FBS) (Cultilab, Campinas, Brazil), 10,000 $\mathrm{U} / \mathrm{mL}$ penicillin/streptomycin (Gibco, Grand Island, NY). Passages were carried out by detaching the cells with $0.25 \%$ trypsin-1mM tetrasodium EDTA (Gibco, Grand Island, NY). For differentiation, cells were plated on coverslips pre-coated with poly-L-lysine (Sigma, St. Louis, MO) and incubated in DMEM/F12 medium containing $6 \mathrm{~g} / \mathrm{L}$ glucose, $1 \mathrm{~g} / \mathrm{L}$ sodium bicarbonate, 3\% (v/v) FBS, $10,000 \mathrm{U} / \mathrm{mL}$ penicillin/streptomycin and $100 \mathrm{ng} / \mathrm{mL}$ nerve growth factor (NGF) (Calbiochem, La Jolla, CA). The cultures were kept in a $5 \% \mathrm{CO}_{2}$ atmosphere at $37{ }^{\circ} \mathrm{C}$ and $100 \%$ humidity.

After 5 days of differentiation as described above, $\mathrm{CNh}$ and $\mathrm{CTb}$ cell lines were incubated with $20 \mu \mathrm{M} \quad 2,4-$ dinitrophenol (2,4-DNP; Sigma, St. Louis, MO), 3-nitrophenol (3-NP; Aldrich Chem., St. Louis, MO) or 4-anisidine (4-AA; kindly provided by Dr. J. D. FigueroaVillar, Military Institute of Engineering, Rio de Janeiro, Brazil) for 48 hours. Neuronal survival was determined using the Live/Dead kit (Molecular Probes, Inc., Eugene, OR) following manufacturer's instructions. Cells were examined and counted on a Nikon Eclipse TE300 microscope. Live cells were identified by green calcein fluorescence, while dead cells were identified by red etidium fluorescence. Two to five random fields were chosen per coverslip, and about 500 cells were counted on each field. Three independent assays were performed (2-4 cover slips per assay). Viabilities are expressed as percentage of cell survival (means \pm SEM). Statistical significances were evaluated using unpaired Student's t-test.

For Congo Red (CR) staining, $\mathrm{CNh}$ and $\mathrm{CTb}$ cells were differentiated for five days and were then treated with $20 \mu \mathrm{M}$ 2,4-DNP, 3-NP or 4-AA for 48 hours, as described above. CR staining of intracellular amyloidcontaining vesicular bodies was performed following a slight modification of the protocol described in (Puchtler and Sweat, 1965). Briefly, cells were fixed with $4 \%$ formaldehyde for $20 \mathrm{~min}$ at room temperature and washed 3 times with PBS. The coverslips were sequentially incubated in $80 \%$ ethanol saturated with sodium chloride plus $1 \% \mathrm{KOH}$ for $30 \mathrm{~min}$ and in alkaline Congo Red (Sigma, St. Louis, MO) solution $(0.2 \%$ in $80 \%$ ethanol saturated with sodium chloride plus $1 \% \mathrm{KOH}$ ) for 30 min. Dehydration was performed by washing the cover slips sequentially in solutions of increasing ethanol concentrations ranging from $50 \%$ to $96 \%$. The coverslips were cleared in xylene and mounted in Entellan mounting medium (Sigma, St. Louis, MO). Congo Red staining was scored by examination of 3-5 random fields per cover slip under bright field microscopy and was expressed as percentage of cells containing intracellular Congo Red-positive vesicular bodies.

For intracellular calcium level measurements, $\mathrm{CNh}$ and $\mathrm{CTb}$ cells were plated on cover slips. After 5 days of differentiation, cells were incubated with 20 $\mu \mathrm{M}$ 2,4-DNP, 3-NP or 4-AA for 48 hours. $\left[\mathrm{Ca}^{2+}\right]_{\mathrm{i}}$ was assessed by microfluorometry using Indo-1 AM (Molecular Probes, Eugene, OR). Cells were incubated at $37^{\circ} \mathrm{C}$ for 40 min with $5 \mu \mathrm{M}$ Indo-1 AM (Molecular Probes) supplemented with $0.005 \%$ Pluronic $(0.1 \%$ dimethyl sulfoxide). The composition of the extracellular solution was (in $\mathrm{mM}$ ): 140 $\mathrm{NaCl}, 5 \mathrm{KCl}, 2 \mathrm{MgCl}_{2}, 1.5$ or $2.5 \mathrm{CaCl}_{2}, 10$ 4-(2-hidroxyethil) piperazine-1ethanesulfonic acid (HEPES)-NaOH and 10 Dextrose $(\mathrm{pH}=7.4)$. The coverslips were mounted in a perfusion chamber placed on the stage of an inverted fluorescence microscope (Diaphot-200, Nikon Corp.) equipped with two dichroic mirrors. One dichroic mirror was used for excitation (355 $\mathrm{nm})$ and the fluorescence emitted by Indo-1 $(>400 \mathrm{~nm}$ ) was split by the second dichroic mirror into beams of light centered at 410 and $485 \mathrm{~nm}$, respectively. The intensities at 
both wavelengths were continuously measured using two photomultipliers, and the analog signal was digitized using an A/ D converter board (Labmaster, Scientific Solutions Inc, Mentor, $\mathrm{OH}$ ) installed in a dedicated PC compatible computer. Data were stored in the hard disk for later analysis. A computer program calculated the $\mathrm{F} 410 / \mathrm{F} 485$ ratio and yielded the corresponding $\left[\mathrm{Ca}^{2+}\right]_{i}$ from a calibration curve obtained with a calcium calibration buffer kit (Molecular Probes, Inc.). Recordings were independently obtained from 10-15 individual cells per cover slip (three cover slips per experiment). Statistical significances were assessed using unpaired Student's t-test, at values of $\mathrm{p}<$ 0.05 .

\section{RESULTS}

Figure 1 shows results from the determination of the percentages of Congo Red (CR)-positive cells in $\mathrm{CNh}$ and $\mathrm{CTb}$ cultures treated for 48 hours with $20 \mu \mathrm{M}$ 2,4-DNP, 3-NP or 4-AA. Control, untreated $\mathrm{CNh}$ (Figure 1A) and $\mathrm{CTb}$ (Figure 1B) cultures, exhibited cells containing intracellular vesicular bodies that were positively stained with CR (52\% CRpositive cells in control CTb cultures versus $30 \%$ CR-positive cells in control $\mathrm{CNh}$ cultures). Treatment with 4-AN induced a large reduction in the percentage of $\mathrm{CR}$ positive $\mathrm{CTb}$ cells (down to $19 \% \mathrm{CR}$ positive cells; Fig. 1C). Figure 1C also shows that treatment with 2,4-DNP and 3NP caused significant decreases in the percentages of $\mathrm{CR}$-positive $\mathrm{CTb}$ cells. In the case of $\mathrm{CNh}$ cells, there were no statistically significant changes in the percentages of cells containing intracellular amyloid in the presence of any of the compounds investigated.

Figure 2 shows cell viabilities of $\mathrm{CNh}$ and CTb cultures treated with $20 \mu \mathrm{M} 2,4-$ DNP, 3-NP or 4-AN. For both cell lines, viabilities ranged from $91-93 \%$ in both control and drug-treated cultures, indicating that 2,4-DNP, 3-NP and 4-AN exhibited no toxicity to $\mathrm{CNh}$ and $\mathrm{CTb}$ cells at the concentrations used in this study.
Figure 3 shows the effects of 2,4-DNP, 3-NP and 4-AN on intracellular calcium levels of $\mathrm{CNh}$ and $\mathrm{CTb}$ cells. In agreement with a previous report (Cárdenas et al., 1999), trisomic cells exhibited a slightly higher basal $\left[\mathrm{Ca}^{2+}\right]_{\mathrm{i}}$ than normal cells. Treatment with 2,4-DNP and 4-AN caused slight increases in intracellular calcium levels of $\mathrm{CNh}$ cells. On the other hand, an increase in intracellular calcium level of $\mathrm{CTb}$ cells was only noted in the presence of 3-NP.

\section{DISCUSSION}

The presence and intracellular processing of APP are normal features in normal neurons, as this protein plays major roles in the regulation of several important cellular functions, especially in the nervous system, where it is involved in synaptogenesis and synaptic plasticity (Gralle and Ferreira, 2007). In agreement with the latter and previous results (Opazo et al, 2006, Arriagada et al. 2007), both $\mathrm{CNh}$ and $\mathrm{CTb}$ cells presents APP immunoreactivity in intracellular compartments. The results presented here show that 2,4-DNP, 3-NP and 4-AN decrease intracellular accumulation of amyloid in $\mathrm{CTb}$ cells without affecting cell viability. It is also interesting to note that the decrease in intracellular amyloid content induced by these compounds was quite significant in trisomic cells, but the percentages of CRpositive cells in normal $\mathrm{CNh}$ cultures were not affected by the inhibitors. Moreover, 4anisidine, the most effective compound in terms of the decrease in the percentage of CR-positive cells (Fig. 1C), caused no alterations in intracellular calcium concentration in CTb cells (Fig. 3).

It remains to be elucidated whether the compounds investigated here disaggregate amyloid aggregates in the cytoplasmic vesicular bodies, interfere with intracellular formation and accumulation of APP, or both. Considering the incubation time of the cells with the compounds $(48 \mathrm{~h})$, it is possible that they interfere with one or more steps of amyloid processing pathways. However, the compounds tested here have been shown to 

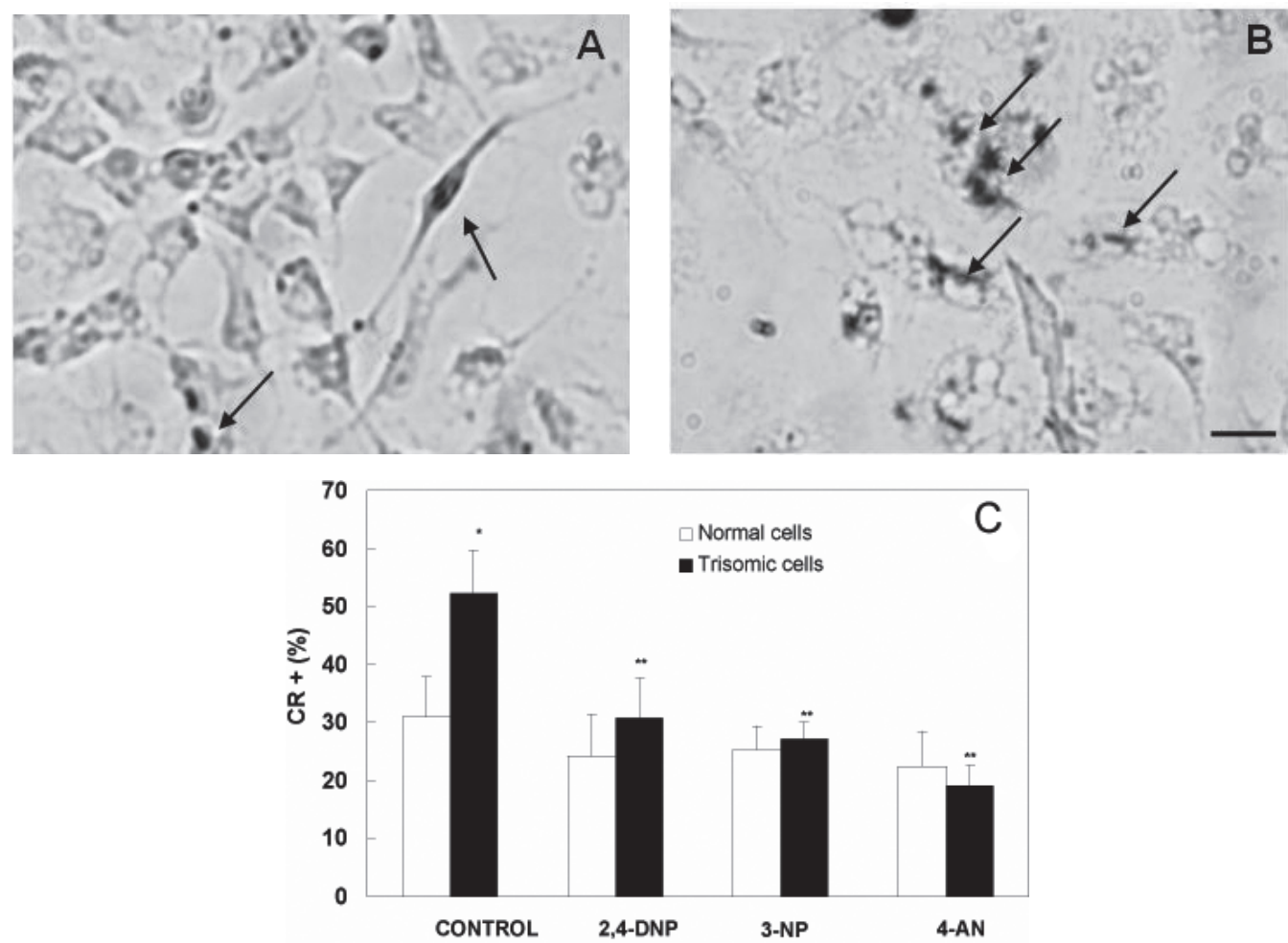

Figure 1: Amyloid aggregation inhibitors reduce intracellular amyloid accumulation in CTb cells. CNh and CTb cells were differentiated for 5 days (see "Methods") and were maintained for two additional days in culture in the absence or in the presence of different compounds $(20 \mu \mathrm{M})$ before staining with Congo Red (CR). Panels A and B: CNh (A) and CTb (B) cells stained with CR and observed under bright field microscopy. Arrows point to some examples of cells containing CR-positive vacuoles in both cell lines. Scale bar: $25 \mu \mathrm{m}$. Panel C: Percentage of CR-positive cells in cultures treated with different compounds. Statistical significances were evaluated using unpaired Student's t-test. * $\mathrm{p}<0.02$ compared to untreated CNh cells; **p $<0.02$ compared to untreated CTb cells.

prevent the formation and to disaggregate previously formed amyloid fibrils and soluble oligomers in vitro (De Felice et al, 2001, 2004), and to prevent aggregation of amyloidogenic variants of human lysozyme, which are involved in hereditary systemic amyloidosis (Vieira et al., 2006).

The observed effects on $\mathrm{Ca}^{2+}$ homeostasis are also interesting. Increased APP level in DS neurons has been linked to lipoperoxidation (Begnia et al., 2003), which could affect $\mathrm{Ca}^{2+}$ channel function. Moreover, Pollard et al. (1995) described that the $\mathrm{A} \beta$ peptide forms $\mathrm{Ca}^{2+}$ channels in artificial bilayers, with conductances of the order of 400 to $4000 \mathrm{pS}$. A channel of such conductance would dissipate the $\mathrm{Ca}^{2+}$ gradient quickly, altering the intracellular homeostasis of the cation, which could deeply impair cell function. As well, altered APP metabolism in DS impairs mitochondrial function, which could render cells more susceptible to oxidative stress and alter $\mathrm{Ca}^{2+}$ homeostasis (Busciglio et al., 2002). The compounds tested here not only did not reduce $\left[\mathrm{Ca}^{2+}\right]_{\mathrm{i}}$ but induced further small increases in its concentration. One possible explanation for this effect could reside in the well-known effect of phenolderived molecules in the uncoupling of oxidative phosphorylation, which could contribute to an energy crisis that further alters $\mathrm{Ca}^{2+}$ regulation. However, we note that measurements of oxygen consumption and mitochondrial potential in neuroblastoma cells treated with $20 \mu \mathrm{m}$ of 


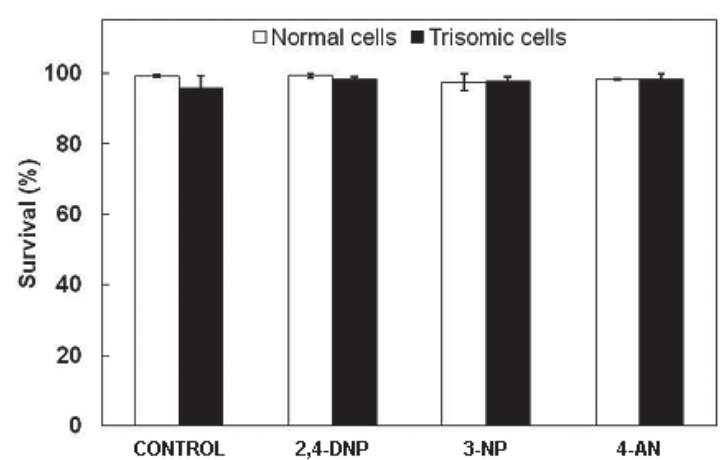

Figure 2: Amyloid aggregation inhibitors are non-toxic to $\mathbf{C N h}$ and $\mathbf{C T b}$ cells. Viabilities, measured using the Live/Dead assay (as described in "Methods"), of $\mathrm{CNh}$ and $\mathrm{CTb}$ cultures treated with 2,4-DNP, 3-NP and 4-AN for 48 hours. Three independent assays were performed (2-4 cover slips per assay). Viabilities are expressed as percentage of live cells. The data correspond to means \pm SEM of three independent assays. From three to seven thousand cells were counted in each experimental condition. No statistically significant differences in viabilities in comparison to control were found after the treatment with the small molecule inhibitors.

the compounds investigated here showed that, at this low concentration, the compounds do not interfere with mitochondrial function (WasilewskaSampaio, 2005). Furthermore, 4-anisidine, a non-phenol, had no effect on $\left[\mathrm{Ca}^{2+}\right]_{\mathrm{i}}$ of trisomic cells but induced a marked reduction in the number of $\mathrm{CR}(+)$ cells. It is, thus, tempting to speculate that the effects of the compounds on APP metabolism and intracellular amyloid accumulation may encompass other mechanisms not involving regulation of intracellular $\mathrm{Ca}^{2+}$, but we acknowledge that this hypothesis requires further study.

Recent results indicate that intracellular amyloid accumulation in the CTb cell line may be due to impairment in the lysosomal/ endosomal pathways (Arriagada et al., 2007). In agreement with this hypothesis, it has been shown that trisomy 21 leads to endosomal abnormalities that are associated with increased soluble $A \beta$ levels and with the presence of intraneuronal $\mathrm{A} \beta$

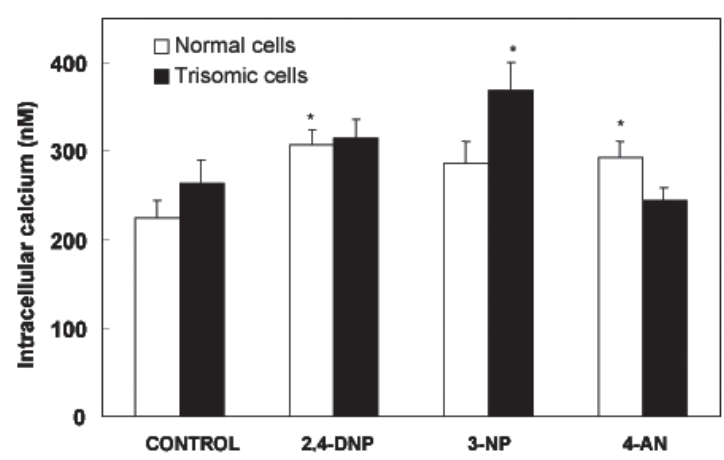

Figure 3: Intracellular calcium concentrations in drug-treated cells. After 48 hours of incubation in the absence or in the presence of $20 \mu \mathrm{M} 2,4-\mathrm{DNP}, 3-\mathrm{NP}$ or $4-\mathrm{AN}$, $\mathrm{CTb}$ or $\mathrm{CNh}$ cells were loaded with the fluorescent calcium indicator Indo-1. Recordings were obtained from 10-15 individual cells per cover slip (three cover slips per experiment) and were converted to intracellular calcium concentrations using a calibration curve, as described in "Methods". Data are means \pm SEM of three independent experiments. Statistical significances were evaluated using unpaired Student's t-test. $* \mathrm{p}<$ 0.02 compared to the respective untreated control.

immunoreactivity, which co-localizes to enlarged endosomes (Cataldo et al, 2000). It has also been shown that a segmental trisomy 16 mouse model of Down syndrome exhibits endosomal abnormalities (Cataldo et al, 2003) and it was proposed that progressive alterations in lysosomal function in $\mathrm{AD}$ and $\mathrm{DS}$ may contribute to the neurodegenerative processes. This mechanism, associated with the gene overdose effect in the trisomic condition, could greatly impair APP metabolism and lead to its intracellular accumulation. Recently, Almeida et al. (2006) shed light on the mechanism by which such abnormalities of late-endosomal sorting occur, by showing that this impairment is related to an inhibition of ubiquitinproteasome system in response to intracellular amyloid accumulation.

In the present work, we have not determined which fragments of APP accumulated in CR-positive vesicular bodies. Western blot analysis of cell lysates 
revealed an APP fragment of about $98 \mathrm{kDa}$, which is immunoreactive to a commercial antibody against $A \beta$ 1-40/42 (data not shown), indicating that it encompasses the $A \beta$ sequence. This suggests that the intracellular vesicular bodies probably contain aggregates of an amyloidogenic nature that are positively stained with CR. Regardless of the precise nature of the amyloid species present, the results presented here show that the smallmolecule compounds tested were capable of reducing the percentage of $\mathrm{CTb}$ cells containing CR-positive vesicular bodies.

\section{CONCLUSION}

Taken together with previous results (De Felice et al., 2001, 2004), the data presented here suggest that 2,4-DNP, 3-NP and 4-AN may be useful lead compounds for the development of drugs that target both extracellular deposition and intracellular accumulation of amyloid fragments.

\section{ACKNOWLEDGEMENTS}

This work was supported by grants from Fondecyt (1040862), Univ. of Chile (VID ENL-02/11 and ENL 07/05) and Fondation Jérôme Lejeune, Paris, France (to PC), Howard Hughes Medical Institute, Conselho Nacional de Desenvolvimento Científico e Tecnológico, Fundação de Amparo à Pesquisa do Estado do RJ and FINEP/CT-Verde Amarelo (to STF).

\section{REFERENCES}

1. ALLEN DD, MARTIN J, ARRIAGADA C, CÁRDENAS AM, RAPOPORT SI, CAVIEDES R, CAVIEDES P (2000) Impaired cholinergic function in cell lines derived from the cerebral cortex of normal and trisomy 16 mice. Eur J Neurosci 12: 3259-3264

2. ALMEIDA CG, TAKAHASHI RH, GOURAS GK (2006) $\beta$-amyloid accumulation impairs multivesicular body sorting by inhibiting the ubiquitin-proteasome system. J Neurosci 26: 4277-4288

3. ARRIAGADA C, ASTORGA C, ATWATER I, ROJAS E, MEARS D, CAVIEDES R CAVIEDES (2007) Endosomal abnormalities related to amyloid precursor protein in cholesterol treated cerebral cortex neuronal cells derived from trisomy 16 mice, an animal model of Down syndrome. Neurosci Lett: 423 173-177
4. BEGNIA B, BRIGHINA L, FUMAGALLIA L, ANDREONIA S, CASTELLI E, FRANCESCONIC C, DEL BO R, BRESOLIN N, FERRARESE C (2003) Altered glutamate uptake in peripheral tissues from Down Syndrome patients. Neurosci Lett 343: 73-76

5. BUSCIGLIO J, PELSMAN A, WONG C, PIGINO G, YUAN M, MORI H, YANKNER BA (2002) Altered metabolism of the amyloid $\beta$ precursor protein is associated with mitochondrial dysfunction in Down's syndrome. Neuron 33: 677-688

6. CÁRDENAS AM, RODRÍGUEZ MP, CORTÉS MP, ÁLVAREZ RM, WEI MP, RAPOPORT SI, SHIMAHARA T, CAVIEDES R, CAVIEDES P (1999) Calcium signals in cell lines derived from the cerebral cortex of normal and trisomy 16 mice. NeuroReport 10: 363-369

7. CATALDO AM, PETERHOFF CM, TRONCOSO JC, GOMEZ-ISLA T, HYMAN BT, NIXON RA (2000) Endocytic pathway abnormalities precede amyloid beta deposition in sporadic Alzheimer's disease and Down syndrome: differential effects of APOE genotype and presenilin mutations. Am J Pathol 157: 277-286

8. CATALDO AM, PETANCESKA S, PETERHOFF CM, TERIO NB, EPSTEIN CJ, VILLAR A, CARLSON EJ, STAUFENBIEL M, NIXON RA (2003) APP gene dosage modulates endosomal abnormalities of Alzheimer's disease in a segmental trisomy 16 mouse model of Down syndrome. J Neurosci 23: 6788-6792

9. DE FELICE FG, HOUZEL JC, GARCÍA-ABREU J, LENT R, LOUZADA PR Jr., AFONSO RC, MEIRELLES MN, NETO VM, FERREIRA ST (2001) Inhibition of Alzheimer's disease beta-amyloid aggregation, neurotoxicity, and in vivo deposition by nitrophenols: implications for Alzheimer's therapy. FASEB J 7: 1297-1299

10. DE FELICE FG, FERREIRA ST (2002) Beta-amyloid production, aggregation, and clearance as targets for therapy in Alzheimer's disease. Cell Mol Neurobiol 22: 545-563

11. DE FELICE FG, VIEIRA MN, SARAIVA LM, FIGUEROA-VILLAR JD, GARCIA-ABREU J., LIU R, CHANG L, KLEIN WL, FERREIRA ST (2004) Targeting the neurotoxic species in Alzheimer's disease: inhibitors of A? oligomerization. FASEB J 18: 1366-1372

12. ECHEVERRÍA V, CUELLO AC (2002) Intracellular $\mathrm{A} \beta$ amyloid, a sign for worse things to come? Mol Neurobiol 26: 299-316

13. FERREIRA ST, VIEIRA MN, DE FELICE FG (2007) Soluble protein oligomers as emerging toxins in Alzheimer's and other amyloid diseases. IUBMB Life.59(4-5):332-45.

14. GALDZICKI Z, SIAREY RJ (2003) Understanding mental retardation in Down's syndrome using trisomy 16 mouse models. Genes Brain Behav 2: 167-178

15. GELLER LN, POTTER H (1999) Chromosome missegregation and trisomy 21 mosaicism in Alzheimer's disease. Neurobiol Dis 6: 167-179

16. GLABE C (2001) Intracellular mechanisms of amyloid accumulation and pathogenesis in Alzheimer's disease. J Mol Neurosci 17: 137-145

17. GOURAS GK, TSAI J, NASLUND J, VINCENT B, EDGAR M, CHECLER F, GREENFIELD JP, HAROUTUNIAN V, BUXBAUM JD, XU H, GREENGARD P, RELKIN NR (2000) Intraneuronal Abeta42 accumulation in human brain. Am J Pathol 156: $15-20$

18. GOURAS GK, ALMEIDA CG, TAKAHASHI RH (2005) Intraneuronal Abeta accumulation and origin of 
plaques in Alzheimer's disease. Neurobiol Aging 26: 1235-1244

19. GRALLE M, FERREIRA, ST (2007) Structure and functions of the human amyloid precursor protein: The whole is more than the sum of its parts. Progress in Neurobiology 82: 11-32

20. HAASS C, SELKOE DJ (2007) Soluble protein oligomers in neurodegeneration: lessons from the Alzheimer's amyloid beta-peptide. Nat Rev Mol Cell Biol 8: 101-112

21. HARDY J, SELKOE DJ (2002) The amyloid hypothesis of Alzheimer's disease: progress and problems on the road to therapeutics. Science 297: 353-356

22. KIENLEN-CAMPARD P, MIOLET S, TASIAUX B, OCTAVE JN (2002) Intracellular amyloid-beta 1-42, but not extracellular soluble amyloid-beta peptides, induces neuronal apoptosis. J Biol Chem 277: 1566615670

23. LACOR PN, BUNIEL MC, FURLOW PW, CLEMENTE AS, VELASCO PT, WOOD M, VIOLA KL, KLEIN WL (2007) A oligomer-induced aberrations in synapse composition, shape, and density provide a molecular basis for loss of connectivity in Alzheimer's disease. J Neurosci 27: 796-807

24. LANGUI D, GIRARDOT N, EL HACHIMI KH, ALLINQUANT B, BLANCHARD V, PRADIER L, DUYCKAERTS C (2004) Subcellular topography of neuronal Abeta peptide in APPxPS1 transgenic mice. Am J Pathol 165: 1465-1477

25. LORENZO A, YANKNER BA (1994) Beta-amyloid neurotoxicity requires fibril formation and is inhibited by congo red. Proc Nat Acad Sc USA 91: 12243-12247

26. OPAZO P, SAUD $K$, DE SAINT PIERRE $M$, CÁRDENAS AM, ALLEN DD, SEGURA-AGUILAR J, CAVIEDES R, CAVIEDES P (2006) Knockdown of amyloid precursor protein normalizes cholinergic function in a cell line derived from the cerebral cortex of a trisomy 16 mouse: an animal model of Down Syndrome. J Neurosci Res 84:1303-1310

27. PIKE CJ, WALENCEWICZ-WASSERMAN AJ,
KOSMOSKI J, CRIBBS DH, GLABE CG, COTMAN CW (1995) Structure-activity analyses of beta-amyloid peptides: contributions of the beta 25-35 region to aggregation and neurotoxicity. J Neurochem 64: 253265

28. POLLARD HB, ARISPE N, ROJAS E (1995) Ion channel hypothesis for Alzheimer amyloid peptide neurotoxicity. Cell Mol Neurobiol 15: 513-526

29. PUCHTLER H, SWEAT F (1965) Congo red as a stain for fluorescence microscopy of amyloid. J Histochem Cytochem 13: 693-694

30. SAUD K, ARRIAGADA C, CÁRDENAS AM, SHIMAHARA T, ALLEN DD, CAVIEDES R, CAVIEDES P (2006) Neuronal dysfunction in Down syndrome: Contribution of neuronal models in cell culture. J Physiol Paris 99: 201-210

31. SELKOE DJ (1991) The molecular pathology of Alzheimer's disease. Neuron 6: 487-498

32. TAKAHASHI RH, MILNER TA, LI F, NAME E, EDGAR MA, YAMAGUCHI H, BEAL MF, XU H, GREENGARD P, GOURAS GK (2002) Intraneuronal Alzheimer Abeta42 accumulates in multivesicular bodies and is associated with synaptic pathology. Am J Pathol 161: 1869-1879

33. VIEIRA MN, FIGUEROA-VILLAR JD, MEIRELLES MN, FERREIRA ST, DE FELICE FG (2006) Small molecule inhibitors of lysozyme amyloid aggregation. Cell Biochem Biophys 44: 549-553

34. WASILEWSKA-SAMPAIO AP, SILVEIRA MS HOLUB O, GOECKING R, GOMES FC, NETO VM, LINDEN R, FERREIRA ST, DE FELICE FG (2005) Neuritogenesis and neuronal differentiation promoted by 2,4-dinitrophenol, a novel anti-amyloidogenic compound. FASEB J 19: 1627-1636

35. WIRTHS O, MULTHAUP G, CZECH C, BLANCHARD V, MOUSSAOUI S, TREMP G, PRADIER L, BEYREUTHER K, BAYER TA (2001) Intraneuronal Abeta accumulation precedes plaque formation in beta-amyloid precursor protein and presenilin-1 double-transgenic mice. Neurosci Lett 306: 116-120 